\title{
Publication Trends in The SA Journal of Physiotherapy for the Decade 1985 - 1994
}

ABW Dladla, final year physiotherapy
student

- Lumede, senior lecturer, Physiotherapy department

- Lin PhD, senior research scientist,
Microbiology

- T Puckree PhD, senior lecturer, Physiotherapy department

\section{University of Durban-Westville}

\section{Introduction}

The South African Journal of Physiotherapy is a forum for South African physiotherapists to share their research findings, advances in clinical practice and education, new techniques and

\section{ABSTRACT}

The primary purpose of this study was to determine trends in the types and first authorship of articles that appeared in the South African Journal of Physiotherapy for the decade, 1985-1994. All 140 articles in the 40 issues of the South African Journal of Physiotherapy for the decade were classified as either research or non-research articles. Research articles using qualitative methodologies were distinguished from those with quantitative ones. First authors of the articles were classified as either physiotherapy academics, physiotherapy students, clinicians or nonphysiotherapists. The results show no significant difference in the number of research vs. non-research articles published for the decade. More non-research articles were published in the first five year period while research articles predominated in the second five year period. Quantitative studies using the experimental method appeared significantly more often in the first five years compared to the second five year period. The majority of the papers were first authored by physiotherapists especially academics. Methodologies and first authorship of papers published in the South African Journal of Physiotherapy revealed an interesting trend, thereby providing clues to growth points and deficits within the profession.

\section{ABSTRAK}

Die vernaamste doel van hierdie studie was om die neiging in die tipe en eerste outeurskap van die artikels wat in die Suid Afrikaanse Tydskrif van Fisioterapie vir die dekade 1985-1994, verskyn het, te bepaal. Al 140 artikels in die 40 uitgawes van die lydskrif vir die dekade was as navorsing of nie-navorsing artikels geklassifiseer. Navorsing artikels wat kwaliteit-metodiek gebruik het was onderskei van dié wat hoeveelheidmetodiek gebruik het. Eerste skrywers van die artikels was as fisioterapie akademikus, fisioterapie student, kliniese fisioterapeut of niefisioterapeut geklassifiseer. Die uitslag bewys geen belangrike verskil in die nommer van navorsing teen nie-navorsing artikels gepubliseer vir die dekade nie. Meer nie-navorsing artikels was in die eerste vyf-jaar periode gepubliseer terwyl navorsing artikels in die meerderheid was in die tweede vyf-jaar periode. Hoeveelheid-studies wat die experimentelemetodiek gebruik het, het meer in die eerste vyf jaar verskyn as vergelyk word met die tweede vyf-jaar periode. Die meeste van die artikels was eerste deur 'n fisioterapie akademikus geskryf. Metodiek en eerste outeurskap het ' $n$ interessante neiging getoon, en daardeur leidrade vir verbouingspunte en tekorte in die beroep verskaf. approaches with their colleagues. The Journal therefore should reflect the standard of physiotherapy education, research and practice, in this country. Concern has been expressed by members of the profession about contributions made to the Journal by physiotherapists ${ }^{1}$ and that the contents of the Journal does not really reflect the standards of physiotherapy in South Africa. However, since the Journal is the only form of communication between the profession and the outside world, it is imperative that a critical review of publication trends within the Journal forms one starting point of assessing the grow th of the profession.

Since the grow th of any profession depends on the ability of the profession to validate clinical practice and educational methods through objective scientific research, the contents of the Journal should provide valuable clues about the direction in which the profession is moving. Previous research by Mitchell ${ }^{2,3}$ suggests that the majority $(69 \%-75 \%)$ of the papers published between 1984-1988, and 1980-1989 were descriptive in nature. Mitchell ${ }^{2}$ classified an article as descriptive if it was principally a description of a technique, case study or basic principles. Since a case study is a form of qualitative research method, Mitchell's $\mathrm{s}^{2,3}$ findings do not really provide any information about the types of articles i.e. qualitative ${ }^{4,5}$ (survey, case study etc.) vs. quantitative $^{4,5}$ (experimental, clinical) vs. non-research articles appearing in the South African Journal of Physiotherapy.

Mitchell's studies also categorised the authors of the articles in the South African Journal of Physiotherapy. It is clear in her studies that the majority of the articles in the South African Journal of Physiotherapy for the decade 1980-1989 were authored by physiotherapy academicians. However, it is not known whether this trend continued beyond 1989.

The primary purpose of the present study was to critically categorise the articles appearing in the South African Journal of Physiotherapy in terms of qualitative, quantitative and non-research articles in order to determine trends in publication of the decade 1985-1994. Secondly to determine who the first authors of the publications were in order to determine whether publication in the Journal is supported and sustained by members of the profession.

\section{Materials and Methods}

\section{Sample}

The sample consisted of all articles $(n=140)$ appearing in the South African Journal of Physiotherapy for the decade 1985-1994. All reports of special interest groups or meetings were excluded from the analysis.

\section{Methods}

Articles were classified initially as research or non-research. Research articles were those articles that used some kind of research methodology, qualitative or quantitative ${ }^{4,5}$. Non-research articles were those articles that gave a description of a technique, approach, or gave more information about a subject, including review papers. Research articles were further classified as qualitative (survey or case study) or quantitative (experimental or 
clinical studies) $)^{4,5}$. First authors of paipers were categorised as academicians, clinicians, physiotherapy students and others (those who were not physiotherapists). Only first authors were included in the analysis because presumably this author motivated the publication in the first instance.

\section{Data Analysis}

The data about type of article and first author were tabulated for each year and means calculated for each five year period, (1985-1989) and (1990-1994) and for the decade 1985-1994. Means were used to determine whether any differences in publication trends or first authorship existed between the earlier and later five year periods compared to the ten year period. Independent two tailed T-tests were used to determine significant differences between the numbers of research and non-research articles, qualitative vs. quantitative research and first author physiotherapy academicians vs. first author non-physiotherapists. Probability was set at 0.05 .

\section{Results}

\begin{tabular}{|c|c|c|c|c|c|c|}
\hline \multicolumn{7}{|c|}{ Table I. Trend in type of article } \\
\hline \multirow[t]{2}{*}{ Year } & \multicolumn{2}{|c|}{ Research } & \multicolumn{2}{|c|}{ Non-research } & \multicolumn{2}{|c|}{ Tofal } \\
\hline & $n$ & $\%$ & $n$ & $\%$ & $\mathbf{n}$ & $\%$ \\
\hline 1985 & 10 & 53 & 9 & 47 & 19 & \\
\hline 1986 & 7 & 47 & 8 & 53 & 15 & \\
\hline 1987 & 4 & 25 & 12 & 75 & 16 & \\
\hline 1988 & 5 & 29 & 12 & 70 & 17 & \\
\hline 1989 & 5 & 42 & 7 & 58 & 12 & \\
\hline 1990 & 9 & 64 & 5 & 36 & 14 & \\
\hline 1991 & 7 & 70 & 3 & 30 & 10 & \\
\hline 1992 & 8 & 80 & 2 & 20 & 10 & \\
\hline 1993 & 10 & 83 & 2 & 17 & 12 & \\
\hline 1994 & 10 & 67 & 5 & 33 & 15 & \\
\hline Total & 75 & 53 & 65 & 47 & 140 & 100 \\
\hline $1985-1989$ & 31 & $39^{*}$ & $4 B$ & 61 & 79 & 100 \\
\hline $1990-1994$ & 44 & $72^{* *}$ & 17 & $2 B$ & 61 & 100 \\
\hline \multicolumn{7}{|c|}{$\begin{array}{l}{ }^{*} \text { Number of research arlicles significantly less that non-research articles } \\
* * \text { Number of research articles significantly greater than non-research articles } \\
p<0.05\end{array}$} \\
\hline
\end{tabular}

As shown in Table I a total of 140 articles were published in the 40 issues of the South African Journal of Physiotherapy for the decade 1985-1994. Numbers of research vs. non-research articles fluctuated per year. Over the 10 year period, 1985-1994, the numbers of research articles published was not significantly different from that of non-research articles. However, for the first five year period (1985-1989), a significantly greater number of non-research articles appeared in the Journal. This trend was reversed in the second five year period when significantly more research articles were published compared to that of non-research papers.

A breakdown of research articles into qualitative and quantitative methodologies as demonstrated in Table Il shows that for the decade under study, the number of papers with quantitative methodologies was not significantly different from those papers which utilised qualitative methodologies. However, in the first five year period (1985-1989) significantly more quantitative papers were published compared to qualitative papers. The majority of quantitative papers were experimental in nature. In the second five year period (1990-1994) equal numbers of qualitative and quantitative papers were published in the Journal. The majority of the qualitative papers utilised the survey method to collect data while the experimental methodology dominated the quantitative papers.

\section{Table II. Trend in type of research article}

\begin{tabular}{|c|c|c|c|c|c|c|c|c|c|}
\hline \multirow[t]{3}{*}{ Year } & \multicolumn{4}{|c|}{ Qualitative } & \multicolumn{4}{|c|}{ Quantitative } & \multirow{3}{*}{$\frac{\text { Total }}{n}$} \\
\hline & \multicolumn{2}{|c|}{ Survey } & \multicolumn{2}{|c|}{ Case study } & \multicolumn{2}{|c|}{ Clinical } & \multicolumn{2}{|c|}{ Experimental } & \\
\hline & n & $\%$ & $n$ & $\%$ & n & $\%$ & & 8 & \\
\hline 1985 & 4 & 40 & 1 & 10 & & 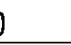 & 5 & 50 & 10 \\
\hline 1986 & 2 & 29 & & & 1 & 14 & 4 & 57 & 7 \\
\hline 1987 & 1 & 25 & & & 2 & 50 & 1 & 25 & 4 \\
\hline 1988 & 1 & 20 & 1 & 20 & & 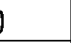 & 3 & 60 & 5 \\
\hline 1989 & 2 & 40 & & & & 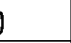 & 3 & 60 & 5 \\
\hline 1990 & 4 & 44 & & & 2 & 27 & 3 & 33 & 9 \\
\hline 1991 & 4 & 57 & 1 & 14 & & 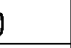 & 2 & 29 & 7 \\
\hline 1992 & 1 & 12.5 & & & & 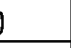 & 7 & 87.5 & 8 \\
\hline 1993 & 6 & 60 & 1 & 10 & & 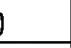 & 3 & 30 & 10 \\
\hline 1994 & 5 & 50 & & & & 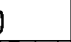 & 5 & 50 & 10 \\
\hline Tolal & 30 & 40 & 4 & 5 & 5 & 7 & 36 & $4 B$ & 75 \\
\hline 1985.1989 & 10 & 32 & 2 & 6 & 3 & 10 & 16 & 52 & 31 \\
\hline 1990-1994 & 20 & 45.5 & & 4.5 & 2 & 4.5 & 20 & 45 & 44 \\
\hline 1985.1989 & & 12139 & $9 \%)^{*}$ & & & & $(61 \%)$ & & 31 \\
\hline 1990.1994 & & 2215 & 50) & & & & $(50 \%)$ & & 44 \\
\hline $1985-1994$ & & $34(45$ & $15 \% 0$ & & & & $(55 \%)$ & & 75 \\
\hline
\end{tabular}

\begin{tabular}{|c|c|c|c|c|c|c|c|c|c|}
\hline \multicolumn{10}{|c|}{ Table III. Trend in first authorship of articles } \\
\hline \multirow[t]{2}{*}{ Year } & \multicolumn{2}{|c|}{ Academic } & \multicolumn{2}{|c|}{ Student } & \multicolumn{2}{|c|}{ Clinicion } & \multicolumn{2}{|c|}{ Other } & \multirow{2}{*}{$\begin{array}{c}\text { Total } \\
\mathbf{n}\end{array}$} \\
\hline & $\mathbf{n}$ & $\%$ & $\mathbf{n}$ & $\%$ & $\mathbf{n}$ & $\%$ & $\mathbf{n}$ & $\%$ & \\
\hline 1985 & 9 & 47 & 1 & 5 & 3 & 16 & 6 & 32 & 19 \\
\hline 1986 & 5 & 33 & \multicolumn{2}{|c|}{0} & 4 & 27 & 6 & 40 & 15 \\
\hline 1987 & 2 & 13 & 1 & 6 & 5 & 31 & B & 50 & 16 \\
\hline 1988 & 3 & 18 & 2 & 12 & 5 & 29 & 7 & 41 & 17 \\
\hline 1989 & 9 & 76 & 1 & 8 & 1 & 8 & 1 & 8 & 12 \\
\hline 1990 & 5 & 36 & 2 & 14 & 4 & 29 & 3 & 21 & 14 \\
\hline 1991 & 7 & 70 & 1 & 10 & 1 & 10 & 1 & 10 & 10 \\
\hline 1992 & 4 & 40 & 1 & 10 & 2 & 20 & 3 & 30 & 10 \\
\hline 1993 & 6 & 50 & 2 & 17 & \multicolumn{2}{|c|}{0} & 4 & 33 & 12 \\
\hline 1994 & $B$ & 53 & 1 & 7 & 1 & 7 & 5 & 33 & 15 \\
\hline Total & 58 & 41 & 12 & 8.5 & 26 & \multicolumn{2}{|c|}{18.544} & 32 & 140 \\
\hline $1985-1989$ & 28 & 35.5 & 5 & 6.5 & 18 & \multicolumn{2}{|c|}{23.528} & 35.5 & 79 \\
\hline $1990-1994$ & 30 & $49 *$ & 7 & 12 & 8 & 13 & 16 & 26 & 61 \\
\hline 1985.1994 & \multicolumn{6}{|c|}{$96(68 \%)^{* *}$} & 44 & 32 & 140 \\
\hline $1985-1989$ & \multicolumn{6}{|c|}{$51(64.5 \%)^{* *}$} & 28 & 35.5 & 79 \\
\hline $1990-1994$ & \multicolumn{6}{|c|}{$45(7 \%)^{* *}$} & 16 & 26 & 61 \\
\hline \multicolumn{10}{|c|}{$\begin{array}{l}\text { *Articles by academics significanily grealer than by non-physiotherapists } \\
{ }^{* *} \text { Significant difference between articles by physiotherapists vs. non-physiotherapists } \\
p<0.05\end{array}$} \\
\hline
\end{tabular}

Table III shows that the majority of the papers published per year for the decade 1985-1994 were authored either by physiotherapy academicians or non-physiotherapists. However, for the entire decade and the second five year period, a significantly greater number of papers were authored by physiotherapy academicians compared to any other category of author. The first five year period saw an equal number of papers authored by physio- 
therapy academicians and non-physiotherapists. A collapse of author categories into physiotherapists compared with nonphysiotherapy authors showed significantly more papers authored by members of the host profession.

\section{Discussion}

The number of articles published over each five year period and the decade compares favourably with that of other physiotherapy periodicals in the rest of the world ${ }^{6}$.

Publications in the South African Journal of Physiotherapy showed a tendency to include more research articles compared to non-research articles in the second five year period under study. This trend is a clear indication of an evolving and growing profession. Robertson ${ }^{6}$ found a similar trend in the American Journal of Physical Therapy, but the evolvement in Physical Therapy occurred many decades earlier. Although quantitative methodologies predominated in the first five year period, qualitative papers appeared more frequently in the second five year period. The majority of the papers were authored by physiotherapists with physiotherapy academicians carrying the larger load.

The results of this study cannot be directly compared to those published by Mitchell $^{2,3}$ because her categorisation of articles was different from the present study. These findings add to Mitchell's results which reveals some very important aspects of the publications which appear in the South African Journal of Physiotherapy. The categorisation of articles in the present study was focused on determining the status of research in this country which is reflected to some extent in the publications which appear in the

\section{0'Grady Peyton's unique USA Sponsorship Programme for Physiotherapists}

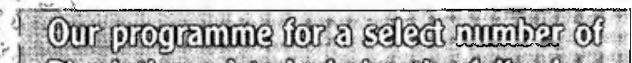
Phystottierapistos tirduries the followitige

Ore week allexpenses paid IRIP TO BOSION, USA to sit the NPT Exam Full STUDY PROGRAMME and REVIEW SEMINAR

Customised salary and benefits package

* $18 / 24$ MONTH contracts

* HIB Visa / Green Card

Our Sponsorship Programme has been established over the past year in order to meet the changing needs of both our client therapists and our client facilities Developments in the healthcare market and in licensing regulations in the USA have led to the need for therapists to hold FULL and UNRESTRICTED license prior to taking up their CONTRACT.

PRESENTATIONS by USA recruitment team throughout South Africa during mid March. Please fax your C.V. for a personal invitation to: Joanne Murray on (021) 8525508

Blandford House, 67 Caledon St. P.0. Box 766, Somerset West 7129 Tel: (021) 8516114 Fax: (021) 8525508 email; ogpsa@iafrica.com
Journal of Physiotherapy. Trends in the methodologies used will help to focus both the profession and educational institutions towards goals set in terms of growth of the profession. Does the profession want to see more qualitative research which has its merits and place in physiotherapy research and in the national health plan or does it want to see more quantitative research which will help the profession validate clinical practice and build a solid foundation for the profession. A balance between the two types of research together with some informational papers which are more of the review type rather that personal opinions about subject matter is likely to strengthen the professional base of knowledge ${ }^{6}$.

Beenhakker indicated a need for more experimental and clinical trials in physiotherapy in South Africa ${ }^{1}$. Our findings of a significantly greater number of research articles (qualitative and quantitative) over that of non-research articles shows that this change is taking place. The fluctuation between qualitative and quantitative papers between the first and second five year periods and the ten year period may indicate that the profession is still trying to address its shortfalls probably in post-graduation education.

As far as first authorship of articles are concerned our results show a trend which is not similar to that of Mitchell. The earlier five year period (1985-1989) which is almost the same as that studied by Mitchell saw no difference in the numbers of papers authored by physiotherapy academicians compared to nonphysiotherapists. The subsequent five year period and the decade saw physiotherapy academicians responsible for the majority of the publications. This study showed that physiotherapists including students, academicians and clinicians a re making a significant contribution to the Journal of Physiotherapy in this country.

\section{Conclusion}

The findings of this study confirm a trend in type and authorship of articles that appear in the South African Journal of Physiotherapy for the decade 1985-1994. These findings can be used as a starting point to address the scientific grow th of the profession. The period under review is the period when almost all training centres in this country had replaced the diploma in physiotherapy with a Bachelors degree. One of the prerequisites for graduation is a research project. Is the profession reaping the benefits of an improved curriculum in the Bachelors degree programme? As in the United States ${ }^{7}$, a grow th in quality graduate programmes with strong research emphasis is likely to be reflected in the publication trends in the South African Journal of Physiotherapy. Further research is needed, to look in to the effects of strategies implemented by the profession and education centres on trends in the Journal of Physiotherapy.

\section{References}

1. Beenhakker J. Editorial. SA fournal of Physiotherapy 1991;47(4):62.

2. Mitchell J. Trends in Physiotherapy research in South Africa 1980-1989. SA fournal of Plysiotheritpy 1990;46(4):17-20.

3. Mitchell J. A Survey of Research Publications in the South African Journal of Physiotherapy. SA Journal of Plyysiotheripy 1990;46(3):7-10.

4. Polgar S, Thomas SA. Introduction to Research in the Health Sciences. 3rd edition. London: Clmrchill Livingstone, 1995:12.

5. Slater SB. The Design of Clinical Research. Phys Ther 1966;46(3):265-273.

6. Robertson VJ. A Quantitative Analysis of Research in Physical Therapy. Plyys Ther 1995;75(4):313-327.

7. Robertson VJ. Research and Cumulation of Knowledge in Physical Therapy. Phys Ther 1995;75(3):223-236. 


\section{Guidelines For Authors}

\section{The Type of Article}

Contributions to the South African Joumal of Plysiotherapy are invited on any topic related to physiotherapy or rehabilitation.

A full-length article may be

- a report on research

- a description of an approach

- a literature review

- a presentation of a theory.

A short report may be

- a case report

- a clinical report

- a treatment technique or suggestion.

Legal Considerations

Contributions will be considered for publication in the

South African Joumal of Plyssiotherapy on condition that

- they have not been published previously.

- they have not been submitted for publication elsewhere.

- the Publications Division of the SASP reserves the copyright of all material published.

Acceptance

Articles are accepted on the understanding that they are subject to editorial revision.

\section{Presentation}

\section{Articles}

- articles should be restricted to between 2,000 and 2,500 words.

- the three copies submitted should be typewritten with double spacing and wide margins.

- word processors may be used provided the typeface is clear and legible.

- a title page should be supplied as a separate sheet and include the name(s), qualifications and affiliation(s) of the author(s), together with addresses and telephone numbers (at home and at work).

- each article must be accompanied by a summary of not more than 200 words. This should be on a separate sheet. It should be intelligible without reference to the main text.

- key words which sum up the content of the article which are not a duplication of the title may be included. Three words are sufficient for referencing and indexing.

- all abbreviations should be spelt out when first used.

- the metric system is to be used throughout.

\section{Letters to the editor}

- if a letter is intended for the correspondence column it should be marked "for publication".

- it should not be longer than 400 words.

\section{References}

- all references should be typed on a separate sheet.

- references should be cited in sequential order. Do not list them alplabetically.

- they are identified in the text by superscript arabic numbers.

- references should be set out in the Vancouver style and only approved abbreviations of journal titles should be used.

- it is the author's responsibility to verify references from the original sources.

- "Unpublished observations" and "personal communications" may be cited in the text, but not in the reference list.

- manuscripts accepted but not yet published may be cited, followed by "(in press)".

The format for references is as follows:

Journals: Not more than three authors

1. Ellison P, Browning C, Larson B et al. A scoring system for the Milani-Comparetti and Gidoni method of neurologic assessment in infancy. Pliys Ther 1983;63:1414-142.

2. Pryor JA and Webber BA. An evaluation of the forced expiration technique as an adjunct to postural drainage. Plysiotherapy 1979;65(10):304-307.

Books:

1. Maitland G D. Vertebral Manipulation. 4th ed. London: Butterworths, 1977: 24.

2. Lipow HW and McQuitty JC. Cystic Fibrosis. In: Rudolf AM, ed. Pediatrics. Norwalk, Connecticut: Appleton-CenturyCrofts, 1982:1433-1440.

\section{Illustrations}

- tables and figures should be kept to a minimum and be on separate sheets.

- each table should be numbered and have a clear title. Tables should not repeat material stated in the text. All tables and figures must be referenced in the text in sequential order.

- figures should be in black ink on stiff white paper. The lettering should be done professionally or by means of a stencil to allow for reduction in size.

- photocopies are not acceptable.

- graphics printed on dot-matrix printers are not acceptable.

- photographs should be of good quality on glossy paper. Human subjects must not be identifiable or their pictures must be accompanied by written permission to use the photograph.

- all illustrations should be clearly marked on the reverse side with arabic numerals, author's name and article, and an indication of the top side.

- all legends must be typed on a separate sheet.

- if a figure has been published before, the author must submit written permission from the copyright holder to reproduce the material.

\section{Manuscript submission}

- a covering letter, which must include the signature of each co-author, should accompany each manuscript.

- the original copy of the paper as well as two copies, must be submitted. A further copy of the manuscript should be retained by the author.

- a word-processing file, in WordPerfect 5.1, on a floppy may be included.

- permission to reprint figures or extracts from other publications should be included with the manuscript on submission. 